\title{
Transcriptional Control of Vascular Smooth Muscle Cell Proliferation by Peroxisome Proliferator-Activated Receptor- $\gamma$ : Therapeutic Implications for Cardiovascular Diseases
}

\author{
Florence Gizard and Dennis Bruemmer \\ Division of Endocrinology and Molecular Medicine, University of Kentucky College of Medicine, Lexington, KY 40536, USA \\ Correspondence should be addressed to Dennis Bruemmer, dennis.bruemmer@uky.edu
}

Received 19 July 2007; Accepted 24 October 2007

Recommended by Giulia Chinetti

Proliferation of vascular smooth muscle cells (SMCs) is a critical process for the development of atherosclerosis and complications of procedures used to treat atherosclerotic diseases, including postangioplasty restenosis, vein graft failure, and transplant vasculopathy. Peroxisome proliferator-activated receptor (PPAR) $\gamma$ is a member of the nuclear hormone receptor superfamily and the molecular target for the thiazolidinediones (TZD), used clinically to treat insulin resistance in patients with type 2 diabetes. In addition to their efficacy to improve insulin sensitivity, TZD exert a broad spectrum of pleiotropic beneficial effects on vascular gene expression programs. In SMCs, PPAR $\gamma$ is prominently upregulated during neointima formation and suppresses the proliferative response to injury of the arterial wall. Among the molecular target genes regulated by PPAR $\gamma$ in SMCs are genes encoding proteins involved in the regulation of cell-cycle progression, cellular senescence, and apoptosis. This inhibition of SMC proliferation is likely to contribute to the prevention of atherosclerosis and postangioplasty restenosis observed in animal models and proof-of-concept clinical studies. This review will summarize the transcriptional target genes regulated by PPAR $\gamma$ in SMCs and outline the therapeutic implications of PPAR $\gamma$ activation for the treatment and prevention of atherosclerosis and its complications.

Copyright ( 92008 F. Gizard and D. Bruemmer. This is an open access article distributed under the Creative Commons Attribution License, which permits unrestricted use, distribution, and reproduction in any medium, provided the original work is properly cited.

\section{INTRODUCTION}

Most cardiovascular diseases result from complications of atherosclerosis, which is a multifactorial process characterized by chronic inflammation, lipid accumulation, and the formation of a complex atherosclerotic lesion [1]. Recruitment of monocytes, their differentiation into macrophages, and uptake of LDL-derived cholesterol are the major cellular events contributing to early fatty streak formation $[2,3]$. Continued intracellular cholesterol accumulation results in the generation of endogenous inducers of inflammatory and proliferative gene expression and a broad range of cellular and humoral responses contributing to lesion initiation and progression [4]. The resulting chronic inflammatory state and the enrichment of lipid-laden macrophages ultimately lead to the formation of a complex atherosclerotic lesion [5].

During the course of atherosclerotic lesion formation, secreted growth factors and cytokines promote the migration and proliferation of vascular smooth muscle cells (SMCs) to contribute to neointima formation [6]. This chronic proliferative response of SMCs promotes further lesion development through the production of proinflammatory mediators and the synthesis of extracellular matrix molecules, which is required for the retention of lipoproteins and often constitutes the majority of the protein content of the advanced lesion responsible for luminal obstruction [1]. However, SMC proliferation within the developing lesion may also exert beneficial effects by forming a fibrous cap covering the advanced atherosclerotic lesion, an important mechanism for the stability of the plaque [7]. The result of this chronic process is the development of an advanced atherosclerotic lesion, which may ultimately cause luminal obstruction and ischemic complications.

Once occlusive atherosclerotic disease has developed, the standard of care may include angioplasty, coronary artery bypass grafting, or cardiac transplantation. However, all current treatment approaches are limited by a varying degree of treatment failure and reocclusion of the arterial lumen. 
Among the cellular mechanisms responsible for this failure of the current interventional procedures used to treat occlusive atherosclerotic diseases, such as postangioplasty restenosis, transplant vasculopathy, and coronary artery bypass graft failure, SMC proliferation constitutes a prime mechanism [6]. In the past decade, elegant progress in interventional cardiology has provided the introduction of drug-eluting stents delivering rapamycin or paclitaxel into the vessel wall that target SMC proliferation [8]. However, despite initial enthusiasm, the complete inhibition of the healing response using these approaches may leave a thrombogenic vessel surface at risk of in-stent thrombosis and vessel occlusion [9]. Thus, despite these advances, ideal therapy for occlusive vascular disease is still far from established.

In an era marked by the increasing prevalence of obesity, diabetes, and cardiovascular disease, members of the nuclear hormone receptor superfamily have emerged as transcription factors that regulate diverse aspects of metabolism $[10,11]$. In addition to their function to act as molecular sensors of lipid and carbohydrate homeostasis, several members of the nuclear hormone receptor family, including the peroxisome proliferator activated receptor (PPAR) $\gamma$, also exert beneficial pleiotropic effects to reduce atherosclerosis and its complications $[12,13]$. PPAR $\gamma$ is the molecular target for the synthetic thiazolidinediones (TZD), such as rosiglitazone and pioglitazone, clinically used as insulin sensitizers in patients with type 2 diabetes [14]. Over the last decade, a wealth of evidence has supported a beneficial role for TZD $\operatorname{PPAR} \gamma$ agonists in the regulation of vascular gene expression programs $[12,13]$. While PPAR $\gamma$ expression itself is increased in response to vascular injury [15-17], its activation by TZD suppresses SMC proliferation through several mechanisms involving the regulation of genes encoding proteins in SMC migration [15], proliferation [15], differentiation [18], senescence [19], and apoptosis [16]. In the following review, we will discuss the role of PPAR $y$ in vascular biology with respect to the control of proliferative gene expression programs that underlie SMC proliferation and the development of cardiovascular diseases.

\section{PPAR $\gamma$ : A LIGAND-ACTIVATED TRANSCRIPTON FACTOR EXPRESSED IN VASCULAR CELLS}

The detailed structure and molecular biology of PPAR $\gamma$ have previously been outlined in excellent review articles $[11,20]$. Briefly, the PPAR subfamily of nuclear receptors consists of 3 isoforms, that is, PPAR $\alpha$ (NR1C1), PPAR $\beta$ (also known as $\delta, \mathrm{NR} 1 \mathrm{C} 2)$, and PPAR $\gamma$ (NR1C3). PPARs regulate gene expression upon heterodimerization with the retinoid $\mathrm{X}$ receptor (RXR, or NR2B) and subsequent binding to specific response elements located in the promoter regions of target genes. Although presently there are no proven pathways for endogenous ligands in vivo, all PPARs are activated in vitro by fatty acids (FAs). PPAR $\gamma$ is activated by the prostaglandin D2 derivative 15-deoxy- $\Delta^{12,14}$-prostaglandin J2 (15d-PGJ2) [21] and forms of oxidized linoleic acid, 9- and 13(S)-HODE [22]. Synthetic PPAR $\gamma$ ligands include TZD, such as troglitazone, rosiglitazone, and pioglitazone, as well as non-TZD derivates. PPAR $\gamma$ is predominantly expressed in adipose tis- sue and has been characterized as an important regulator of adipocyte differentiation and glucose homeostasis [14]. Based on their efficacy to improve insulin sensitivity, the TZD PPAR $y$ ligands rosiglitazone and pioglitazone are currently being utilized in clinical practice to treat insulin resistance in patients with type 2 diabetes $[23,24]$.

In addition to the metabolic effect of PPAR $\gamma$, the receptor is expressed in atherosclerotic lesions $[15,25]$ and in all vascular cell types including endothelial cells (EC) [26], macrophages [27], T lymphocytes [28], and SMCs [29]. In EC, PPAR $\gamma$ is activated in response to atheroprotective laminar flow [30]. Ligand-induced activation of PPAR $\gamma$ in these cells suppresses the expression of genes responsible for the adhesion of monocytes to the endothelium (i.e., VCAM-1 [31, 32], ICAM-1 [33]) and their transendothelial migration [34], which are both crucial early processes for the subsequent development of atherosclerosis. In macrophage biology, PPAR $\gamma$ has been demonstrated to suppress inflammatory gene expression and to decrease intracellular lipid accumulation and foam-cell formation $[35,36]$. Finally, increased PPAR $\gamma$ expression has been demonstrated in neointimal layers during atherosclerotic lesion development $[15,25]$. Concomitant with the phenotypic shift from quiescent SMCs resident in the uninjured vessel wall to proliferating SMCs in the neointima, PPAR $\gamma$ expression is induced in the neointima following vascular injury $[15,16]$. Considering the importance of SMC proliferation during atherosclerosis and its complications [6], this increased expression of PPAR $\gamma$ in neointimal SMCs has provided an important rationale to further exploit the role of PPAR $\gamma$ for the proliferative response that underlies the development of neointima formation and atherosclerotic cardiovascular diseases.

\section{TRANSCRIPTIONAL REGULATION OF SMOOTH MUSCLE CELL PROLIFERATION BY PPAR $\gamma$ LIGANDS}

The physiological state of the SMCs in the arterial wall is determined by endogenous and exogenous signals, and often the endpoint that interpretates these signals is gene transcription [37]. Emerging evidence has implicated PPAR $\gamma$ as a key transcriptional modulator of SMC function. In the following section, we outline the role of PPAR $\gamma$ in the regulation of diverse SMC processes including cell proliferation, cell-cycle progression, senescence, and apoptosis (see Figure 1).

\subsection{Regulation of SMC proliferation and cell-cycle progression by PPAR $\gamma$ agonists}

Mitogenic growth factors secreted during vascular injury converge into a final common signaling pathway regulating the proliferative response of SMCs: the cell-cycle [6] (see Figure 2). While SMCs are in a quiescent state $\left(\mathrm{G}_{0}\right)$ in the uninjured artery, they transit in response to mitogenic stimulation through the $G_{1}$ phase of the cellcycle and ultimately enter $\mathrm{S}$ phase to undergo replication [38]. Cell-cycle progression is under the control of cyclins and cyclin-dependent kinases (CDKs), which phosphorylate the retinoblastoma gene product (pRB) [39]. pRB 


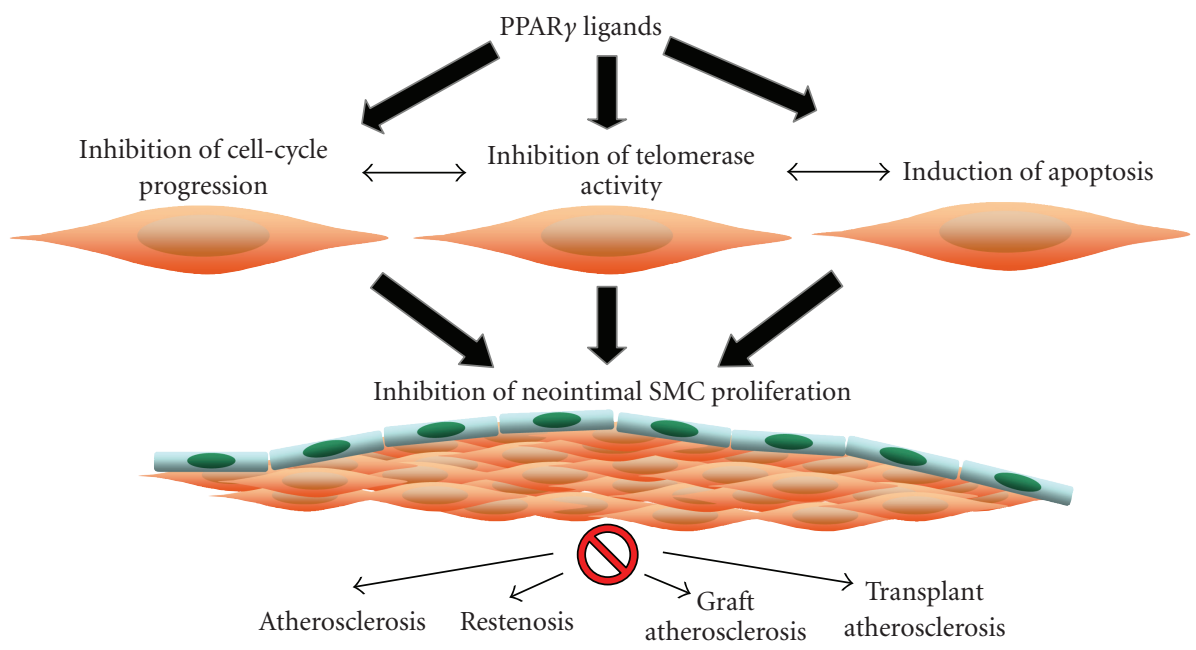

FIGURE 1: Cellular mechanisms involved in the inhibition of SMC proliferation by PPAR $\gamma$ during cardiovascular diseases. PPAR $\gamma$ regulates genes encoding proteins involved in diverse SMC processes including cell proliferation, cell-cycle progression, senescence, and apoptosis.

phosphorylation represents the critical checkpoint of the $\mathrm{G}_{1} \rightarrow \mathrm{S}$ phase transition and increased pRB phosphorylation correlates with the induction of SMC proliferation in injured vessels $[40,41]$. Consistent with this, maintenance of high levels of phosphorylated pRB is required for the development of intimal hyperplasia. Upon pRB phosphorylation, sequestered $\mathrm{E} 2 \mathrm{~F}$ transcription factors are released to induce the transcription of genes involved in the regulation of S phase DNA synthesis [42]. Through CDK-inhibitors (CDKI), including p27 ${ }^{\mathrm{Kip} 1}$, the activity of cyclin/CDK complexes in quiescent SMCs is inhibited providing a second layer of regulation $[43,44]$. In response to mitogens, p2 $7^{\text {Kip } 1}$ undergoes ubiquitination and degradation through the proteasome pathway allowing $\mathrm{CDK} /$ cyclin complexes to phosphorylate $\mathrm{pRB}$ [45]. Therefore, mitogen-induced degradation of $\mathrm{p} 27^{\mathrm{Kipl}}$ is an initial requirement for $\mathrm{pRB}$ phosphorylation and subsequent $\mathrm{G}_{1} \rightarrow \mathrm{S}$ cell-cycle progression [46].

PPAR $y$ ligands have been demonstrated in various studies to prevent mitogen-induced SMC proliferation and the mechanisms by which this inhibition of proliferation occurs appear to involve an arrest in the $G_{1}$ phase of the cell cycle [47-49]. The growth-inhibitory effects of PPAR $\gamma$ agonists were first associated with their ability to prevent mitogen-induced degradation of the CDKI cyclin-dependent kinase inhibitor (CDKI) p27 ${ }^{\mathrm{Kip} 1}$, which inhibits the activity of cyclin/CDK and consequently reduces the cellular levels of phosphorylated pRB [47]. Since in vivo gene transfer of p27 $7^{\text {Kip } 1}$ significantly inhibits neointimal cell proliferation [43], p2 $7^{\text {Kip } 1}$ likely constitutes an important target for the anti-proliferative effects of PPAR $\gamma$ activation. Consistent with its function to suppress the activity of cyclin/CDKcomplexes, stabilization of $\mathrm{p} 27^{\mathrm{Kip} 1}$ by PPAR $\gamma$ ligands has been demonstrated to inhibit cyclin/CDK activity, an effect that ultimately translates into a prevention of mitogeninduced pRB phosphorylation [47].

DNA microarray analysis further identified that minichromosome maintenance proteins (MCM) 6 and 7 are inhibited by PPAR $\gamma$ ligands in SMCs [50]. MCM proteins represent bona fide E2F target genes [51] and play a central role in the regulation of the initiation of DNA replication ensuring that DNA replicates only once during cell cycle (for review see [52]). In eukaryotes, MCM2-MCM7 are recruited onto replication origins during the $G_{1}$ phase of the cell cycle and assembled into a heteromeric hexamer. Formation of this prereplication complex, a process often referred to as "replication licensing", establishes the competence of this origin for the initiation of DNA replication in the subsequent S phase. Therefore, the inhibition of MCM gene expression by PPAR $\gamma$ ligands provides evidence that the inhibitory effects of PPAR $\gamma$ ligands on $\mathrm{G}_{1} \rightarrow \mathrm{S}$ transition are the result of targeting the $\mathrm{pRB} / \mathrm{E} 2 \mathrm{~F} / \mathrm{MCM}$ pathway.

\subsection{PPAR $\gamma$ activation and induction of apoptosis in SMCs}

In addition to the role of TZD in the regulation of $G_{1} \rightarrow S$ cell-cycle progression, several studies have demonstrated that TZD induce apoptosis in SMCs $[16,53,54]$. Among the regulated target genes mediating PPAR $\gamma$-induced apoptosis is the growth-arrest and DNA damage-inducible gene 45 (GADD45) [53]. Molecular analyses demonstrated that PPAR $\gamma$-induced GADD45 gene transcription is mediated through an Oct-1-dependent mechanism [53]. Although the exact function of GADD45 remains unclear, GADD45 has been implicated in growth suppression [55] and apoptosis $[56,57]$. Through its association with Cdc2, GADD45 disrupts the interactions of $\mathrm{Cdc} 2$ with cyclin $\mathrm{B} 1$ and, thus, may induce $\mathrm{G}_{2} / \mathrm{M}$ arrest [58]. The GADD45 gene, therefore, may represent a unique target for drugs that induce cell-cycle arrest, apoptosis, and differentiation such as PPAR $\gamma$ ligands.

The second pathway that has been demonstrated to induce apoptosis by PPAR $\gamma$ ligands involves the induction of transforming growth factor (TGF) $-\beta$ by PPAR $\gamma$ [54]. TGF- $\beta$ is an essential cytokine involved in the control of the balance 


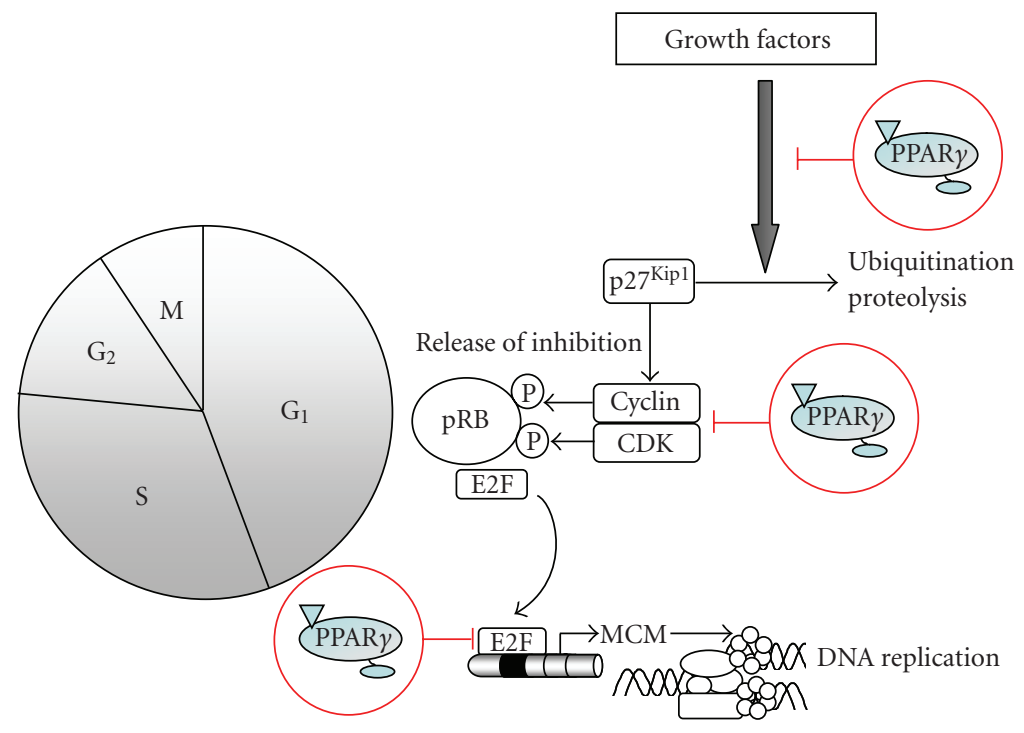

FIGURE 2: PPAR $\gamma$ targets cell-cycle progression. Phosphorylation of the retinoblastoma gene product (pRB) by specific $\mathrm{G}_{1} \mathrm{CDKs}_{\mathrm{N}}$ represents the critical checkpoint of the $G_{1} / S$ transition of the cell cycle. $p R B$ phosphorylation releases E2F allowing the expression of genes required for DNA synthesis. By preventing the degradation of the CDK inhibitor (CDKI) p27 Kip1, PPAR $\gamma$ ligands inhibit mitogen-induced pRB phosphorylation and downstream expression of key E2F-regulated genes (i.e., MCM genes) responsible for the initiation of DNA replication.

between proliferation and apoptosis in SMCs [59]. Previously, TZD-induced apoptosis of SMCs has been suggested to depend on the induction of TGF- $\beta$ and subsequent downstream nuclear recruitment of phospho-Smad2 [54]. Interestingly, TGF- $\beta$-induced apoptosis is partly mediated by Smad-dependent expression of GADD45 [60]. Therefore, it is possible if not likely that GADD45 constitutes a key downstream mediator of apoptosis induced by PPAR $\gamma$ activation.

A third mechanism that has been implicated in PPAR $\gamma$ induced SMC apoptosis involves the transcriptional induction of the interferon regulatory factor-1 (IRF-1), a transcriptional factor with anti-proliferative and proapoptotic properties. Lin et al. recently demonstrated that both TZD and PPAR $\gamma$ overexpression upregulate IRF-1 expression in SMCs [61]. Reducing IRF-1 expression by antisense approaches attenuated PPAR $\gamma$-induced SMC apoptosis suggesting that the PPAR $\gamma$-regulated IRF-1 pathway contributes to the proapoptotic effects observed with TZD.

\subsection{Regulation of SMC telomerase and senescence by PPAR $\gamma$ ligands}

Telomerase has been linked to multiple developmental processes including cell proliferation, senescence, and aging [6264]. Telomeres, the DNA-protein complexes at the ends of chromosomes, are stabilized by the ribonucleoprotein telomerase reverse transcriptase (TERT) to serve as protective capping and to prevent cellular senescence $[65,66]$. In most adult cells TERT expression and telomerase activity are repressed and telomeres shorten during tissue renewal [67], and it has been proposed that this telomere exhaustion is rate limiting for lifespan [68]. Loss of telomere length beyond a critical threshold results in cellular senescence [59], a state in which cells are unresponsive to mitogenic stimuli [69]. These molecular features of telomerase to prevent senescence are highly conserved among eukaryotes and act on somatic cells as biological clock to ultimately result in permanent growth arrest and entry into replicative senescence [70].

In SMCs, telomerase activity is required for cell proliferation, and disruption of telomerase activity reduces atherosclerosis and neointima formation [71-73]. TERT is the limiting factor for telomerase activation in response to mitogenic stimuli and TERT antisense oligonucleotides inhibit SMC proliferation $[71,72]$. This suggests that TERT may play an important role in the regulation of SMC proliferation and neointima formation. A recent study demonstrated that mitogen-induced telomerase activity in SMCs is inhibited by ligand-induced and constitutive PPAR $\gamma$ activation [19]. The transcriptional mechanisms responsible for the suppression of telomerase activity by PPAR $\gamma$ ligands involve an inhibition of Ets-1-dependent transactivation of the TERT promoter [19]. Ets-1 is an early response gene that mediates a variety of growth signals in neointimal SMC proliferation [74]; and atherosclerosis [75] and PPAR $\gamma$ ligands have been reported to inhibit Ets-1 expression [76]. The relevance of telomerase as target for PPAR $\gamma$ was further demonstrated in SMCs overexpressing telomerase, in which the efficacy of PPAR $\gamma$ ligand pioglitazone to inhibit cell proliferation is lost [19]. These studies indicate that telomerase constitutes an important molecular target for the antiproliferative effects of PPAR $\gamma$ activation in SMCs.

\subsection{Ligand-receptor relationship and specificity: is TZD-regulated gene expression in SMCs PPAR $\gamma$-dependent?}

Although the above-described evidence outlines the ability of TZD to suppress SMC proliferation and induce apoptosis, 
it remains controversial whether the cell-cycle-inhibitory effects of TZD occur through a ligand-dependent activation of PPAR $\gamma$. Several experimental approaches have been used by different investigators to specifically address this question, including PPAR $\gamma$-deficient cells [48, 77], overexpression of either dominant-negative or constitutively-active PPAR $\gamma$ mutants $[19,50,53,78]$, or pharmacologic inhibition of PPAR $\gamma[16,53,54,61]$. In PPAR $\gamma$-deficient embryonic stem cells, TZD have been demonstrated to inhibit cell proliferation, which indicated that this effect might occur independent of their binding and activation of PPAR $\gamma$ [77]. In contrast to these earlier studies in stem cells, overexpression of a dominant-negative PPAR $\gamma$ mutant has been demonstrated to increase SMC proliferation in vitro and neointima formation in vivo (discussed in Section 4.1) pointing to a role of PPAR $\gamma$ to function as an endogenous repressor of SMC proliferation [78]. Complementary to these observations, overexpression of a constitutively-active PPAR $\gamma$ induces SMC apoptosis in the absence of ligand [53] while pharmacologic inhibition of PPAR $\gamma$ prevents rosiglitazone-induced apoptosis of neointimal SMCs [16]. In addition, many of the target genes, thought to be involved in the regulation of SMC proliferation/apoptosis by PPAR $y$ ligands, have been demonstrated to be either directly regulated by overexpression of PPAR $\gamma$ or the ligand effect is reversed following pharmacologic inhibition of PPAR $\gamma[16,19,48,50,53,54,61,78,79]$. These studies in concert support the concept that the antiproliferative activity of PPAR $\gamma$ ligands against SMC stems at least in part from a ligand-dependent activation of the receptor. However, further studies including in particular SMC-specific PPAR $\gamma$ deficiency or overexpression are warranted to further support this notion.

A second important question that arises from this discussion relates to ligand specificity and whether the inhibition of SMC proliferation by agonists for PPAR $\gamma$ is exclusively mediated through this receptor or whether PPAR $\gamma$ ligands may also activate PPAR $\alpha$ or $\delta$. Approximately $80 \%$ of the 34 residues defining the ligand binding cavity of PPAR $\gamma$ are conserved across the three receptor isotypes $[11,20]$. In addition, all three isoforms possess unusually large binding pockets, compared to other nuclear receptors, which accommodate a diverse set of lipophilic acids as ligands [80]. Furthermore, anti-proliferative effects of PPAR $\gamma$ ligands are observed at concentrations considerably higher than their $\mathrm{EC}_{50}$ for transcriptional activation in cell-based transfection assays or in in vitro binding assays with isolated ligand-binding domain fragments $[15,81]$. Considering this knowledge, at high concentrations spillover of PPAR $\gamma$-selective ligands to $\operatorname{PPAR} \alpha$ and/or $\operatorname{PPAR} \delta$ is theoretically possible and the antiproliferative activity of TZD observed in PPAR $\gamma$-deficient cells could be explained by their binding to and activation of PPAR $\alpha$ or PPAR $\delta$. Indeed, activation of $\operatorname{PPAR} \alpha$ represses SMC proliferation [82], while $\operatorname{PPAR} \delta$ activation has been reported to stimulate rather than inhibit growth of SMCs [83] and keratinocytes [84]. Although very few studies have directly compared the effects of $\operatorname{PPAR} \gamma, \operatorname{PPAR} \alpha$, and $\operatorname{PPAR} \delta$ ligands on SMC function, Lin et al. recently identified that the above-described IRF-1-dependent apoptosis induced by $\operatorname{PPAR} \gamma$ ligands is selective and not observed with PPAR $\alpha$ or
$\operatorname{PPAR} \delta$ ligands [61]. This study supports ligand selectivity for PPAR $\gamma$ in SMCs, although detailed studies are required to further address this question.

\section{TZD IN THE TREATMENT OF CARDIOVASCULAR DISEASE}

\subsection{Lessons from animal models}

TZD PPAR $y$ ligands have been demonstrated to prevent the development of atherosclerosis in several murine atherosclerosis models including the low-density lipoprotein receptordeficient $\left(\mathrm{LDLR}^{-/-}\right)$and the apolipoprotein $\mathrm{E}$ deficient mouse model (apoE ${ }^{-/-}$) [85-88]. This preventive effect on hyperlipidemia-induced atherosclerosis occurs independently of changes in circulating lipids, blood pressure, glucose, or insulin, implicating direct pleiotropic effects on the vascular wall. Inhibition of atherosclerosis by TZD ligands in these models appears to be also independent of their efficacy to improve insulin sensitivity as the prevention of atherosclerosis is observed in both insulin-sensitive and insulin-resistant models ${ }^{\circ}$ [85-88]. The mechanisms responsible for the prevention of atherosclerosis by TZD in these murine atherosclerosis models likely involve macrophagedriven processes contributing to atherosclerosis since conditional deletion of PPAR $\gamma$ in macrophages accelerates atherosclerosis [89]. In addition, specific deletion of PPAR $\gamma$ in EC has recently been demonstrated to increase blood pressure in mice suggesting that PPAR $\gamma$ in EC is an important regulator of hypertension, which may contribute to the prevention of atherosclerosis in murine models [90].

Consistent with the observations that TZD PPAR $\gamma$ ligands limit SMC proliferation in vitro, Law et al. demonstrated over a decade ago that the TZD ligand troglitazone reduces intimal hyperplasia in a rat carotid artery balloon injury model [91]. Subsequent studies confirmed these observations and demonstrated that TZD inhibit intimal hyperplasia in models of restenosis in both insulin-resistant and insulin-sensitive animals [92-95]. Similarly, Joner et al. recently demonstrated the prevention of in-stent restenosis by TZD ligands using a hypercholesterolemic rabbit atherosclerosis model [96]. Additional beneficial effects of TZD in the process of neointima formation include accelerated reendothelialization, which is mediated through an enhanced differentiation of angiogenic progenitor cells into mature endothelial cells $[97,98]$. As detailed above, the question as to whether the prevention of neointima formation by TZD involves a receptor-dependent pathway has been addressed in a recent study using overexpression of PPAR $\gamma$. While in vivo transfer of an adenoviral vector expressing wild-type PPAR $\gamma$ inhibited SMC proliferation and reduced neointima formation after balloon injury, overexpression of a dominant-negative PPAR $\gamma$ mutant increased neointima formation [78]. These studies have provided the first in vivo evidence to support a direct role of PPAR $\gamma$ in suppressing the proliferative response following vascular injury. 


\subsection{Clinical evidence for vascular protection by TZD}

\subsubsection{Carotid artery intima/media thickness}

Carotid artery intima/media thickness (CIMT) is a welldescribed surrogate marker for cardiovascular risk and correlates not only with the presence of cardiovascular risk factors but also with the risk of future macrovascular events $[99,100]$. The first study that used CIMT to assess whether TZD treatment prevents the progression of atherosclerosis was performed 10 years ago. In this study 57 patients with type 2 diabetes were treated with $400 \mathrm{mg}$ troglitazone, which resulted in a significant decline in CIMT after 3 months of treatment [101]. This reduction in CIMT with troglitazone has been confirmed in a recent cohort of patients with insulin-requiring type 2 diabetes [102]. A similar decline in CIMT was observed a few years later in two independent studies performed with pioglitazone [103, 104]. The recently reported $\mathrm{CHICAGO}$ trial (Carotid Intima-Media Thickness in Atherosclerosis Using Pioglitazone) was a randomized, double-blind, comparator-controlled, multicenter trial in patients with type 2 diabetes assessing the effect of pioglitazone versus the sulfonylurea glimepiride on CIMT progression [105]. In this study of 462 patients the primary endpoint of progression of mean CIMT was less with pioglitazone versus glimepiride after 72 weeks. Notably, the beneficial effect of pioglitazone on mean CIMT was similar across prespecified subgroups based on age, sex, systolic blood pressure, duration of type 2 diabetes, body mass index, $\mathrm{HbA}(1 \mathrm{c})$ value, and statin use. The fourth CIMT study performed with pioglitazone compared the effects of pioglitazone $(45 \mathrm{mg} / \mathrm{d})$ and glimepiride $(2.7+/-1.6 \mathrm{mg} / \mathrm{d})$ in a randomized controlled study of 173 patients with type 2 diabetes [106]. In this study, CIMT was reduced only in the pioglitazone group and not in patients treated with glimepiride and this effect was independent of glycemic control.

Comparable results on CIMT progression have been obtained with rosiglitazone. Sidhu et al. analyzed the effect of rosiglitazone on CIMT progression in a double-blind, placebo-controlled randomized study in 92 non-diabetic patients with documented coronary artery disease [107]. In this study, rosiglitazone therapy revealed a reduced progression in CIMT after 48 weeks of treatment. The Rosiglitazone Atherosclerosis Study analyzed the effect of TZD treatment on CIMT progression in a mixed patient cohort of 555 subjects with type 2 diabetes or insulin resistance [108]. Although in this study there was no effect of rosiglitazone treatment in the mixed population of type 2 diabetes and insulin resistance, in the subanalysis of type 2 diabetic patients there was a reduced progression of CIMT. A third study reported by Stocker et al. analyzed whether rosiglitazone compared to metformin decreased CIMT in 93 subjects with type 2 diabetes [109]. In this study, metformin and rosiglitazone treatment led to similar improvement in glycemic control; however, CIMT progressed in the metformin group while regression of maximal CIMT was observed in the rosiglitazone group.

\subsubsection{Postangioplasty restenosis}

Takagi et al. [110-112] first demonstrated that troglitazone reduced neointimal tissue proliferation after coronary stent implantation in patients with type 2 diabetes mellitus. Following the withdrawal of troglitazone from the market, it was subsequently demonstrated that pioglitazone has similar effects and significantly reduces neointimal tissue proliferation in patients with type 2 diabetes mellitus [113]. In this study, 44 patients with type 2 diabetes and 44 stented lesions were randomized to either pioglitazone therapy or control. Intravascular ultrasound demonstrated that the neointimal index in the pioglitazone group was significantly smaller than that in the control group. Similarly, Nishio et al. observed that the late luminal loss and in-stent restenosis were significantly less in patients treated with pioglitazone [114]. A third study performed with pioglitazone demonstrated in a randomized, placebo-controlled, double-blind trial that pioglitazone significantly reduced neointima volume after coronary stent implantation in patients without diabetes [115].

Comparable results have been obtained with rosiglitazone in a prospective, randomized, case-controlled trial involving 95 diabetic patients with coronary artery disease, which demonstrated that the in-stent restenosis rate was significantly reduced in the rosiglitazone group compared with the control group [116]. However, a second study of a smaller cohort of sixteen patients did not observe a significant decrease in in-stent luminal diameter stenosis measured by quantitative coronary angiography intravascular ultrasound [117]. Finally, the third study performed by Wang et al. suggested that the occurrence of coronary events following angioplasty in 71 patients was significantly decreased in the rosiglitazone group at 6-month follow-up [118]. These studies in concert suggest that TZD therapy in patients undergoing coronary stent implantation may be associated with less in-stent restenosis and repeated revascularization. This notion is further supported by two recent meta-analyses $[119,120]$. However, decisions on clinical use of an adjunctive TZD therapy following coronary interventions must await larger double-blind clinical trials.

\subsubsection{Cardiovascular outcome studies}

The beneficial vascular effects observed with TZD provided the rationale for larger cardiovascular trials and the first results from these studies are beginning to emerge. The Prospective Pioglitazone Clinical Trial in Macrovascular Events (PROactive) trail is a prospective, randomized controlled trial in 5238 patients with type 2 diabetes who had evidence of macrovascular disease [121]. This study tested theeffects of pioglitazone or placebo in addition to their glucose-lowering drugs and other medications on a combined vascular endpoint in patients with known vascular disease. The broad primary endpoint (the composite of all-cause mortality, nonfatal myocardial infarction (including silent myocardial infarction), stroke, acute coronary syndrome, endovascular or surgical intervention in the coronary or leg arteries, and amputation above the ankle) was not statistically different between the pioglitazone and placebo 
arm of the study. However, the study demonstrated a significant $16 \%$ reduction of the main cardiovascular secondary endpoint of all-cause mortality, myocardial infarction, and stroke in type 2 diabetic patients treated with pioglitazone. A recently published subanalysis out of this study further reported the effect of pioglitazone on recurrent myocardial infarction in 2,445 patients with type 2 diabetes and previous myocardial infarction [122]. In this prespecified endpoint, pioglitazone had a statistically significant beneficial effect on fatal and nonfatal MI (28\% risk reduction) and acute coronary syndrome (37\% risk reduction). A second subanalysis from the PROactive trial in patients with previous stroke ( $n=486$ in the pioglitazone group and $n=498$ in the placebo group) further reported that pioglitazone reduced fatal or nonfatal stroke by $47 \%$ [123]. Consistent with the reported side-effect profile for TZD, the PROactive trial confirmed an increased rate of edema and heart failure in patients treated with pioglitazone [121]. However, in this context it is important to note that heart failure was a nonadjudicated event and mortality due to heart failure was not increased compared to the placebo group.

Currently, trials with rosiglitazone are being performed to determine whether rosiglitazone affects cardiovascular outcomes. Three clinical trials are currently testing approaches that use rosiglitazone to reduce cardiovascular disease in patients with diabetes: the Action to Control Cardiovascular Risk in Diabetes (ACCORD) trial [124], the Bypass Angioplasty Revascularization Investigation 2 Diabetes (BARI 2D) trial [125], and The Rosiglitazone Evaluated for Cardiac Outcomes and Regulation of Glycemia in Diabetes (RECORD) trial [126]. A recent meta-analysis of trials performed with rosiglitazone reported an association with a significant increase in the risk of myocardial infarction and with a nonsignificant increase of the risk of death from cardiovascular causes [127]. However, the authors of this meta-analysis acknowledged considerable limitations of their analysis and the National Institutes of Health (supporting the ACCORD and BARI 2D trials) found no evidence in this analysis to require discontinuing the use of rosiglitazone in the trials or to revise the study protocols [128]. Similarly, an interim analysis of the RECORD trial did not show a statistically significant difference between the rosiglitazone group and the control group for the endpoints acute myocardial infarction and death from cardiovascular causes, although patients treated with rosiglitazone were at increased risk to develop heart failure [129]. Therefore, completion of these studies will enable the determination whether rosiglitazone provides a similar reduction in cardiovascular outcomes as seen with pioglitazone and will aid to determine the most appropriate combination therapies for patients with type 2 diabetes.

\section{SUMMARY AND CONCLUSIONS}

Research performed over the last decade has highlighted an important role for TZD-induced PPAR $\gamma$ activation in vascular cells. TZD exert a broad spectrum of anti-inflammatory and anti-proliferative on all cell types participating in the development of cardiovascular diseases. A wealth of evidence from preclinical and clinical studies supports that these pleiotropic effects of TZD translate into reduced atherosclerosis and failure of coronary angioplasty as the primary approach to treat luminal obstruction. The PROactive trial was the first cardiovascular outcome trial to demonstrate that pioglitazone decreases all-cause mortality, myocardial infarction, and stroke in patients with type 2 diabetes. Further studies including the ACCORD, RECORD, and BARI 2D trials will determine whether similar effects are seen with rosiglitazone and outline ideal treatment strategies to reduce cardiovascular disease in patients with type 2 diabetes.

\section{ACKNOWLEDGMENTS}

Dennis Bruemmer is supported by Grants from the National Institutes of Health (HL084611), the American Diabetes Association (Research Award 1-06-RA-17), and the American Heart Association (Scientist Development Grant 0435239N). Florence Gizard is supported by a Postdoctoral Fellowship from the American Heart Association, Great Rivers Affiliate (0725313B).

\section{REFERENCES}

[1] R. Ross, "Atherosclerosis—an inflammatory disease," The New England Journal of Medicine, vol. 340, no. 2, pp. 115126, 1999.

[2] R. P. Choudhury, J. M. Lee, and D. R. Greaves, "Mechanisms of disease: macrophage-derived foam cells emerging as therapeutic targets in atherosclerosis," Nature Clinical Practice Cardiovascular Medicine, vol. 2, no. 6, pp. 309-315, 2005.

[3] C.-P. Liang, S. Han, T. Senokuchi, and A. R. Tall, "The macrophage at the crossroads of insulin resistance and atherosclerosis," Circulation Research, vol. 100, no. 11, pp. 1546-1555, 2007.

[4] G. K. Hansson and P. Libby, "The immune response in atherosclerosis: a double-edged sword," Nature Reviews Immunology, vol. 6, no. 7, pp. 508-519, 2006.

[5] A. Daugherty, "Atherosclerosis: cell biology and lipoproteins," Current Opinion in Lipidology, vol. 16, no. 2, pp. 257 259, 2005.

[6] V. J. Dzau, R. C. Braun-Dullaeus, and D. G. Sedding, "Vascular proliferation and atherosclerosis: new perspectives and therapeutic strategies," Nature Medicine, vol. 8, no. 11, pp. 1249-1256, 2002.

[7] S. M. Schwartz, Z. S. Galis, M. E. Rosenfeld, and E. Falk, "Plaque rupture in humans and mice," Arteriosclerosis, Thrombosis, and Vascular Biology, vol. 27, no. 4, pp. 705-713, 2007.

[8] J. W. Moses, M. B. Leon, J. J. Popma, et al., "Sirolimus-eluting stents versus standard stents in patients with stenosis in a native coronary artery," The New England Journal of Medicine, vol. 349, pp. 1315-1323, 2003.

[9] D. R. Holmes Jr., D. J. Kereiakes, W. K. Laskey, et al., "Thrombosis and drug-eluting stents. An objective appraisal," Journal of the American College of Cardiology, vol. 50, no. 2, pp. 109118, 2007.

[10] A. Chawla, J. J. Repa, R. M. Evans, and D. J. Mangelsdorf, "Nuclear receptors and lipid physiology: opening the $\mathrm{x}$-files," Science, vol. 294, no. 5548, pp. 1866-1870, 2001. 
[11] R. M. Evans, G. D. Barish, and Y.-X. Wang, "PPARs and the complex journey to obesity," Nature Medicine, vol. 10, no. 4, pp. 355-361, 2004.

[12] N. Marx, H. Duez, J.-C. Fruchart, and B. Staels, "Peroxisome proliferator-activated receptors and atherogenesis: regulators of gene expression in vascular cells," Circulation Research, vol. 94, no. 9, pp. 1168-1178, 2004.

[13] J. D. Brown and J. Plutzky, "Peroxisome proliferatoractivated receptors as transcriptional nodal points and therapeutic targets," Circulation, vol. 115, no. 4, pp. 518-533, 2007.

[14] J. M. Olefsky and A. R. Saltiel, "PPAR $\gamma$ and the treatment of insulin resistance," Trends in Endocrinology and Metabolism, vol. 11, no. 9, pp. 362-368, 2000.

[15] R. E. Law, S. Goetze, X. P. Xi, et al., "Expression and function of PPAR $y$ in rat and human vascular smooth muscle cells," Circulation, vol. 101, no. 11, pp. 1311-1318, 2000.

[16] D. Bishop-Bailey, T. Hla, and T. D. Warner, "Intimal smooth muscle cells as a target for peroxisome proliferator-activated receptor- $\gamma$ ligand therapy," Circulation Research, vol. 91, no. 3, pp. 210-217, 2002.

[17] H. Kosuge, G. Haraguchi, N. Koga, Y. Maejima, J.-I. Suzuki, and M. Isobe, "Pioglitazone prevents acute and chronic cardiac allograft rejection," Circulation, vol. 113, no. 22, pp. 2613-2622, 2006.

[18] K. B. Atkins, C. A. Northcott, S. W. Watts, and F. C. Brosius, "Effects of PPAR- $\gamma$ ligands on vascular smooth muscle marker expression in hypertensive and normal arteries," American Journal of Physiology-Heart and Circulatory Physiology, vol. 288, no. 1 57-1, pp. H235-H243, 2005.

[19] D. Ogawa, T. Nomiyama, T. Nakamachi, et al., "Activation of peroxisome proliferator-activated receptor $\gamma$ suppresses telomerase activity in vascular smooth muscle cells," Circulation Research, vol. 98, no. 7, pp. e50-e59, 2006.

[20] J. Berger and D. E. Moller, "The mechanisms of action of PPARs," Annual Review of Medicine, vol. 53, pp. 409-435, 2002.

[21] S. A. Kliewer, J. M. Lenhard, T. M. Willson, I. Patel, D. C. Morris, and J. M. Lehmann, "A prostaglandin J2 metabolite binds peroxisome proliferator-activated receptor $\gamma$ and promotes adipocyte differentiation," Cell, vol. 83, no. 5, pp. 813819, 1995.

[22] L. Nagy, P. Tontonoz, J. G. Alvarez, H. Chen, and R. M. Evans, "Oxidized LDL regulates macrophage gene expression through ligand activation of PPAR $\gamma$," Cell, vol. 93, no. 2, pp. 229-240, 1998.

[23] J. M. Lehmann, L. B. Moore, T. A. Smith-Oliver, W. O. Wilkison, T. M. Willson, and S. A. Kliewer, "An antidiabetic thiazolidinedione is a high affinity ligand for peroxisome proliferator-activated receptor $\gamma$ (PPAR $\gamma$ )," The Journal of Biological Chemistry, vol. 270, no. 22, pp. 12953-12956, 1995.

[24] H. Yki-Jarvinen, "Thiazolidinediones," The New England Journal of Medicine, vol. 351, no. 11, pp. 1106-1118, 2004.

[25] M. Ricote, J. Huang, L. Fajas, et al., "Expression of the peroxisome proliferator-activated receptor $\gamma(\operatorname{PPAR} \gamma)$ in human atherosclerosis and regulation in macrophages by colony stimulating factors and oxidized low density lipoprotein," Proceedings of the National Academy of Sciences of the United States of America, vol. 95, no. 13, pp. 7614-7619, 1998.

[26] X. Xin, S. Yang, J. Kowalski, and M. E. Gerritsen, "Peroxisome proliferator-activated receptor $\gamma$ ligands are potent inhibitors of angiogenesis in vitro and in vivo," Journal of Biological Chemistry, vol. 274, no. 13, pp. 9116-9121, 1999.
[27] C. Jiang, A. T. Ting, and B. Seed, "PPAR- $\gamma$ agonists inhibit production of monocyte inflammatory cytokines," Nature, vol. 391, no. 6662, pp. 82-86, 1998.

[28] N. Marx, B. Kehrle, K. Kohlhammer, et al., "PPAR activators as antiinflammatory mediators in human T lymphocytes: implications for atherosclerosis and transplantationassociated arteriosclerosis," Circulation Research, vol. 90, pp. 703-710, 2002.

[29] B. Staels, W. Koenig, A. Habib, et al., "Activation of human aortic smooth-muscle cells is inhibited by PPAR $\alpha$ but not by PPAR $\gamma$ activators," Nature, vol. 393, no. 6687, pp. 790-793, 1998.

[30] Y. Liu,, Y. Zhu, F. Rannou, et al., "Laminar flow activates peroxisome proliferator-activated receptor- $\gamma$ in vascular endothelial cells," Circulation, vol. 110, no. 9, pp. 1128-1133, 2004.

[31] Q. N. Diep, M. El Mabrouk, J. S. Cohn, et al., "Structure, endothelial function, cell growth, and inflammation in blood vessels of angiotensin II-infused rats: role of peroxisome proliferator-activated receptor- $\gamma$," Circulation, vol. 105, no. 19, pp. 2296-2302, 2002.

[32] S. M. Jackson, F. Parhami, X. P. Xi, et al., "Peroxisome proliferator-activated receptor activators target human endothelial cells to inhibit leukocyte-endothelial cell interaction," Arteriosclerosis, Thrombosis, and Vascular Biology, vol. 19, no. 9, pp. 2094-2104, 1999.

[33] N. Wang, L. Verna, N.-G. Chen, et al., "Constitutive activation of peroxisome proliferator-activated receptor- $\gamma$ suppresses pro-inflammatory adhesion molecules in human vascular endothelial cells," The Journal of Biological Chemistry, vol. 277, no. 37, pp. 34176-34181, 2002.

[34] U. Kintscher, S. Goetze, S. Wakino, et al., "Peroxisome proliferator-activated receptor and retinoid $\mathrm{X}$ receptor ligands inhibit monocyte chemotactic protein-1-directed migration of monocytes," European Journal of Pharmacology, vol. 401, no. 3, pp. 259-270, 2000.

[35] A. C. Li, C. J. Binder, A. Gutierrez, et al., "Differential inhibition of macrophage foam-cell formation and atherosclerosis in mice by $\operatorname{PPAR} \alpha, \beta / \delta$, and $\gamma$," The Journal of Clinical Investigation, vol. 114, no. 11, pp. 1564-1576, 2004.

[36] M. Ricote, A. C. Li, T. M. Willson, C. J. Kelly, and C. K. Glass, "The peroxisome proliferator-activated receptor- $\gamma$ is a negative regulator of macrophage activation," Nature, vol. 391, no. 6662, pp. 79-82, 1998.

[37] O. G. McDonald and G. K. Owens, "Programming smooth muscle plasticity with chromatin dynamics," Circulation Research, vol. 100, no. 10, pp. 1428-1441, 2007.

[38] M. D. P. S. M. Schwartz and M. D. P. C. E. Murry, "Proliferation and the monoclonal origins of atherosclerotic lesions," Annual Review of Medicine, vol. 49, pp. 437-460, 1998.

[39] N. C. Walworth, "Cell-cycle checkpoint kinases: checking in on the cell cycle," Current Opinion in Cell Biology, vol. 12, no. 6, pp. 697-704, 2000.

[40] M. W. Chang, E. Barr, J. Seltzer, et al., "Cytostatic gene therapy for vascular proliferative disorders with a constitutively active form of the retinoblastoma gene product," Science, vol. 267, no. 5197, pp. 518-522, 1995.

[41] J. W. Harbour and D. C. Dean, "Rb function in cell-cycle regulation and apoptosis," Nature Cell Biology, vol. 2, no. 4, pp. E65-E67, 2000.

[42] R. A. Weinberg, "E2F and cell proliferation: a world turned upside down," Cell, vol. 85, no. 4, pp. 457-459, 1996. 
[43] F. C. Tanner, M. Boehm, L. M. Akyurek, et al., "Differential effects of the cyclin-dependent kinase inhibitors p27Kip1, p21Cip1, and p16Ink4 on vascular smooth muscle cell proliferation," Circulation, vol. 101, no. 17, pp. 2022-2025, 2000.

[44] F. C. Tanner, Z.-Y. Yang, E. Duckers, D. Gordon, G. J. Nabel, and E. G. Nabel, "Expression of cyclin-dependent kinase inhibitors in vascular disease," Circulation Research, vol. 82, no. 3, pp. 396-403, 1998.

[45] C. J. Sherr and J. M. Roberts, "CDK inhibitors: positive and negative regulators of G1-phase progression," Genes and Development, vol. 13, no. 12, pp. 1501-1512, 1999.

[46] R. C. Braun-Dullaeus, M. J. Mann, and V. J. Dzau, "Cell cycle progression: new therapeutic target for vascular proliferative disease," Circulation, vol. 98, no. 1, pp. 82-89, 1998.

[47] S. Wakino, U. Kintscher, S. Kim, F. Yin, W. A. Hsueh, and R. E. Law, "Peroxisome proliferator-activated receptor $\gamma$ ligands inhibit retinoblastoma phosphorylation and G1 $\rightarrow$ S transition in vascular smooth muscle cells," Journal of Biological Chemistry, vol. 275, no. 29, pp. 22435-22441, 2000.

[48] D. Bruemmer, J. P. Berger, J. Liu, et al., "A non-thiazolidinedione partial peroxisome proliferator-activated receptor $\gamma$ ligand inhibits vascular smooth muscle cell growth," European Journal of Pharmacology, vol. 466, no. 3, pp. 225-234, 2003.

[49] S. T. de Dios, D. Bruemmer, R. J. Dilley, et al., "Inhibitory activity of clinical thiazolidinedione peroxisome proliferator activating receptor- $\gamma$ ligands toward internal mammary artery, radial artery, and saphenous vein smooth muscle cell proliferation," Circulation, vol. 107, no. 20, pp. 2548-2550, 2003.

[50] D. Bruemmer, F. Yin, J. Liu, et al., "Peroxisome proliferatoractivated receptor $\gamma$ inhibits expression of minichromosome maintenance proteins in vascular smooth muscle cells," Molecular Endocrinology, vol. 17, no. 6, pp. 1005-1018, 2003.

[51] K. Ohtani, R. Iwanaga, M. Nakamura, et al., "Cell growthregulated expression of mammalian MCM5 and MCM6 genes mediated by the transcription factor E2F," Oncogene, vol. 18, no. 14, pp. 2299-2309, 1999.

[52] D. Maiorano, M. Lutzmann, and M. Mechali, "MCM proteins and DNA replication," Current Opinion in Cell Biology, vol. 18, no. 2, pp. 130-136, 2006.

[53] D. Bruemmer, F. Yin, J. Liu, et al., "Regulation of the growth arrest and DNA damage-inducible gene 45 (GADD45) by peroxisome proliferator-activated receptor $\gamma$ in vascular smooth muscle cells," Circulation Research, vol. 93, no. 4, pp. e38-e47, 2003.

[54] S. Redondo, E. Ruiz, C. G. Santos-Gallego, E. Padilla, and T. Tejerina, "Pioglitazone induces vascular smooth muscle cell apoptosis through a peroxisome proliferator-activated receptor- $\gamma$, transforming growth factor- $\beta 1$, and a Smad2dependent mechanism," Diabetes, vol. 54 , no. 3, pp. 811-817, 2005.

[55] Q. Zhan, K. A. Lord, D. A. Liebermann, et al., "The gadd and MyD genes define a novel set of mammalian genes encoding acidic proteins that synergistically suppress cell growth," Molecular and Cellular Biology, vol. 14, no. 4, pp. 2361-2371, 1994.

[56] M. Takekawa and H. Saito, "A family of stress-inducible GADD45-like proteins mediate activation of the stressresponsive MTK1/MEKK4 MAPKKK," Cell, vol. 95, no. 4, pp. 521-530, 1998.

[57] D. P. Harkin, J. M. Bean, D. Miklos, et al., "Induction of GADD45 and JNK/SAPK-dependent apoptosis following in- ducible expression of BRCA1," Cell, vol. 97, no. 5, pp. 575$586,1999$.

[58] X. W. Wang, Q. Zhan, J. D. Coursen, et al., "GADD45 induction of $\mathrm{a}_{2} / \mathrm{M}$ cell cycle checkpoint," Proceedings of the National Academy of Sciences of the United States of America, vol. 96, no. 7, pp. 3706-3711, 1999.

[59] R. Khan, A. Agrotis, and A. Bobik, "Understanding the role of transforming growth factor- $\beta 1$ in intimal thickening after vascular injury," Cardiovascular Research, vol. 74, no. 2, pp. 223-234, 2007.

[60] J. Yoo, M. Ghiassi, L. Jirmanova, et al., “Transforming growth factor- $\beta$-induced apoptosis is mediated by smad-dependent expression of GADD45b through p38 activation," Journal of Biological Chemistry, vol. 278, no. 44, pp. 43001-43007, 2003.

[61] Y. Lin, X. Zhu, and F. L. McLntee, "Interferon regulatory factor-1 mediates PPAR $\gamma$-induced apoptosis in vascular smooth muscle cells," Arteriosclerosis, Thrombosis, and Vascular Biology, vol. 24, no. 2, pp. 257-263, 2004.

[62] M. A. Blasco, "Mice with bad ends: mouse models for the study of telomeres and telomerase in cancer and aging," EMBO Journal, vol. 24, no. 6, pp. 1095-1103, 2005.

[63] N. F. Mathon, D. S. Malcolm, M. C. Harrisingh, L. Cheng, and A. C. Lloyd, "Lack of replicative senescence in normal rodent glia," Science, vol. 2915, no. 5505, pp. 872-875, 2001.

[64] N. E. Sharpless and R. A. DePinho, "Telomeres, stem cells, senescence, and cancer," Journal of Clinical Investigation, vol. 113, no. 2, pp. 160-168, 2004.

[65] C. Autexier and N. F. Lue, "The structure and function of telomerase reverse transcriptase," Annual Review of Biochemistry, vol. 75, pp. 493-517, 2006.

[66] S. B. Cohen, M. E. Graham, G. O. Lovrecz, N. Bache, P. J. Robinson, and R. R. Reddel, "Protein composition of catalytically active human telomerase from immortal cells," Science, vol. 315, no. 5820, pp. 1850-1853, 2007.

[67] C. B. Harley, A. B. Futcher, and C. W. Greider, "Telomeres shorten during ageing of human fibroblasts," Nature, vol. 345 , no. 6274, pp. 458-460, 1990.

[68] A. G. Bodnar, M. Ouellette, M. Frolkis, et al., "Extension of life-span by introduction of telomerase into normal human cells," Science, vol. 279, no. 5349, pp. 349-352, 1998.

[69] N. F. Mathon and A. C. Lloyd, "Cell senescence and cancer," Nature Reviews Cancer, vol. 1, pp. 203-213, 2001.

[70] L. Harrington, W. Zhou, T. McPhail, et al., "Human telomerase contains evolutionarily conserved catalytic and structural subunits," Genes and Development, vol. 11, no. 23, pp. 3109-3115, 1997.

[71] T. Minamino and S. Kourembanas, "Mechanisms of telomerase induction during vascular smooth muscle cell proliferation," Circulation Research, vol. 89, no. 3, pp. 237-243, 2001.

[72] T. Minamino and I. Komuro, "The role of telomerase activation in the regulation of vascular smooth muscle cell proliferation," Drug News and Perspectives, vol. 16, no. 4, pp. 211216, 2003.

[73] E. Poch, P. Carbonell, S. Franco, A. Diez-Juan, M. A. Blasco, and V. Andres, "Short telomeres protect from diet-induced atherosclerosis in apolipoprotein E-null mice," The FASEB Journal, vol. 18, no. 2, pp. 418-420, 2004.

[74] A. Hultgardh-Nilsson, B. Cercek, J. W. Wang, et al., "Regulated expression of the ets-1 transcription factor in vascular smooth muscle cells in vivo and in vitro," Circulation Research, vol. 78, no. 4, pp. 589-595, 1996. 
[75] M. M. Kavurma, Y. Bobryshev, and L. M. Khachigian, "Ets1 positively regulates fas ligand transcription via cooperative interactions with Sp1," Journal of Biological Chemistry, vol. 277, no. 39, pp. 36244-36252, 2002.

[76] S. Goetze, U. Kintscher, S. Kim, et al., "Peroxisome proliferator-activated receptor- $\gamma$ ligands inhibit nuclear but not cytosolic extracellular signal-regulated kinase/mitogenactivated protein kinase-regulated steps in vascular smooth muscle cell migration," Journal of Cardiovascular Pharmacolog, vol. 38, no. 6, pp. 909-921, 2001.

[77] S. S. Palakurthi, H. Aktas, L. M. Grubissich, R. M. Mortensen, and J. A. Halperin, "Anticancer effects of thiazolidinediones are independent of peroxisome proliferator-activated receptor $\gamma$ and mediated by inhibition of translation initiation," Cancer Research, vol. 61, no. 16, pp. 6213-6218, 2001.

[78] S. Lim, C. J. Jin, M. Kim, et al., "PPAR $\gamma$ gene transfer sustains apoptosis, inhibits vascular smooth muscle cell proliferation, and reduces neointima formation after balloon injury in rats," Arteriosclerosis, Thrombosis, and Vascular Biology, vol. 26, no. 4, pp. 808-813, 2006.

[79] D. Bishop-Bailey and T. D. Warner, "PPAR $\gamma$ ligands induce prostaglandin production in vascular smooth muscle cells: indomethacin acts as a peroxisome proliferator-activated receptor- $\gamma$ antagonist," FASEB Journal, pp. 1002-1075, 2003.

[80] R. T. Nolte, G. B. Wisely, S. Westin, et al., "Ligand binding and co-activator assembly of the peroxisome proliferatoractivated receptor- $\gamma$," Nature, vol. 395, pp. 137-143, 1998.

[81] J. Berger, P. Bailey, C. Biswas, et al., “Thiazolidinediones produce a conformational change in peroxisomal proliferatoractivated receptor- $\gamma$ : binding and activation correlate with antidiabetic actions in db/db mice," Endocrinology, vol. 137, no. 10, pp. 4189-4195, 1996.

[82] F. Gizard, C. Amant, O. Barbier, et al., "PPAR $\alpha$ inhibits vascular smooth muscle cell proliferation underlying intimal hyperplasia by inducing the tumor suppressor p16INK4a," Journal of Clinical Investigation, vol. 115, no. 11, pp. 3228-3238, 2005.

[83] J. Zhang, M. Fu, X. Zhu, et al., "Peroxisome proliferatoractivated receptor delta is up-regulated during vascular lesion formation and promotes post-confluent cell proliferation in vascular smooth muscle cells," Journal of Biological Chemistry, vol. 277, no. 13, pp. 11505-11512, 2002.

[84] N. S. Tan, L. Michalik, N. Noy, et al., "Critical roles of $\operatorname{PPAR} \beta / \delta$ in keratinocyte response to inflammation," Genes and Development, vol. 15, no. 24, pp. 3263-3277, 2001.

[85] A. C. Li, K. K. Brown, M. J. Silvestre, T. M. Willson, W. Palinski, and C. K. Glass, "Peroxisome proliferator-activated receptor $\gamma$ ligands inhibit development of atherosclerosis in LDL receptor-deficient mice," The Journal of Clinical Investigation, vol. 106, no. 4, pp. 523-531, 2000.

[86] T. Claudel, M. D. Leibowitz, C. Fievet, et al., "Reduction of atherosclerosis in apolipoprotein E knockout mice by activation of the retinoid X receptor," Proceedings of the National Academy of Sciences of the United States of America, vol. 98, no. 5, pp. 2610-2615, 2001.

[87] A. R. Collins, W. P. Meehan, U. Kintscher, et al., "Troglitazone inhibits formation of early atherosclerotic lesions in diabetic and nondiabetic low density lipoprotein receptordeficient mice," Arteriosclerosis, Thrombosis, and Vascular Biology, vol. 21, no. 3, pp. 365-371, 2001.

[88] Z. Chen, S. Ishibashi, S. Perrey, et al., "Troglitazone inhibits atherosclerosis in apolipoprotein e-knockout mice: pleiotropic effects on CD36 expression and HDL," Arte- riosclerosis, Thrombosis, and Vascular Biology, vol. 21, no. 3, pp. 372-377, 2001.

[89] V. R. Babaev, P. G. Yancey, S. V. Ryzhov, et al., "Conditional knockout of macrophage PPAR $\gamma$ increases atherosclerosis in $\mathrm{C} 57 \mathrm{BL} / 6$ and low-density lipoprotein receptor-deficient mice," Arteriosclerosis, Thrombosis, and Vascular Biology, vol. 25, no. 8, pp. 1647-1653, 2005.

[90] C. J. Nicol, M. Adachi, T. E. Akiyama, et al., "PPAR $\gamma$ in endothelial cells influences high fat diet-induced hypertension," American Journal of Hypertension, vol. 18, no. 4, pp. 549-556, 2005.

[91] R. E. Law, W. P. Meehan, X. P. Xi, et al., "Troglitazone inhibits vascular smooth muscle cell growth and intimal hyperplasia," Journal of Clinical Investigation, vol. 98, no. 8, pp. 1897-1905, 1996.

[92] M. Igarashi, Y. Takeda, N. Ishibashi, et al., "Pioglitazone reduces smooth muscle cell density of rat carotid arterial intima induced by balloon catheterization," Hormone and Metabolic Research, vol. 29, no. 9, pp. 444-449, 1997.

[93] J. W. Phillips, K. G. Barringhaus, J. M. Sanders, et al., "Rosiglitazone reduces the accelerated neointima formation after arterial injury in a mouse injury model of type 2 diabetes," Circulation, vol. 108, pp. 1994-1999, 2003.

[94] T. Yoshimoto, M. Naruse, H. Shizume, et al., "Vasculoprotective effects of insulin sensitizing agent pioglitazone in neointimal thickening and hypertensive vascular hypertrophy," Atherosclerosis, vol. 145, no. 2, pp. 333-340, 1999.

[95] Y. Aizawa, J. Kawabe, N. Hasebe, N. Takehara, and K. Kikuchi, "Pioglitazone enhances cytokine-induced apoptosis in vascular smooth muscle cells and reduces intimal hyperplasia," Circulation, vol. 104, pp. 455-460, 2001.

[96] M. Joner, A. Farb, Q. Cheng, et al., "Pioglitazone inhibits in-stent restenosis in atherosclerotic rabbits by targeting transforming growth factor- $\beta$ and MCP-1," Arteriosclerosis, Thrombosis, and Vascular Biology, vol. 27, pp. 182-189, 2007.

[97] K. M. Hannan, R. J. Dilley, S. T. de Dios, and P. J. Little, "Troglitazone stimulates repair of the endothelium and inhibits neointimal formation in denuded rat aorta," Arteriosclerosis, Thrombosis, and Vascular Biology, vol. 23, pp. 762-768, 2003.

[98] C. H. Wang, N. Ciliberti, S. H. Li, et al., "Rosiglitazone facilitates angiogenic progenitor cell differentiation toward endothelial lineage: a new paradigm in glitazone pleiotropy," Circulation, vol. 109, pp. 1392-1400, 2004.

[99] M. L. Bots, A. W. Hoes, P. J. Koudstaal, et al., "Common carotid intima-media thickness and risk of stroke and myocardial infarction: the Rotterdam Study," Circulation, vol. 96, pp. 1432-1437, 1997.

[100] P. J. Touboul, A. Elbaz, C. Koller, et al., "Common carotid artery intima-media thickness and brain infarction : the Étude du Profil Génétique de l'Infarctus Cérébral (GÉNIC) case-control study. The GENIC Investigators," Circulation, vol. 102, pp. 313-318, 2000.

[101] J. Minamikawa, S. Tanaka, M. Yamauchi, D. Inoue, and H. Koshiyama, "Potent inhibitory effect of troglitazone on carotid arterial wall thickness in type 2 diabetes," The Journal of Clinical Endocrinology and Metabolism, vol. 83, no. 5, pp. 1818-1820, 1998.

[102] H. N. Hodis, W. J. Mack, L. Zheng, et al., "Effect of peroxisome proliferator-activated receptor $\gamma$ agonist treatment on subclinical atherosclerosis in patients with insulin-requiring type 2 diabetes," Diabetes Care, vol. 29, pp. 1545-1553, 2006. 
[103] H. Koshiyama, D. Shimono, N. Kuwamura, J. Minamikawa, and Y. Nakamura, "Rapid communication: inhibitory effect of pioglitazone on carotid arterial wall thickness in type 2 diabetes," The Journal of Clinical Endocrinology and Metabolism, vol. 86, no. 7, pp. 3452-3456, 2001.

[104] T. Nakamura, T. Matsuda, Y. Kawagoe, et al., "Effect of pioglitazone on carotid intima-media thickness and arterial stiffness in type 2 diabetic nephropathy patients," Metabolism, vol. 53, no. 10, pp. 1382-1386, 2004.

[105] T. Mazzone, P. M. Meyer, S. B. Feinstein, et al., "Effect of pioglitazone compared with glimepiride on carotid intimamedia thickness in type 2 diabetes: a randomized trial," The Journal of the American Medical Association, vol. 296, no. 21, pp. 2572-2581, 2006.

[106] M. R. Langenfeld, T. Forst, C. Hohberg, et al., "Pioglitazone decreases carotid intima-media thickness independently of glycemic control in patients with type 2 diabetes mellitus: results from a controlled randomized study," Circulation, vol. 111, pp. 2525-2531, 2005.

[107] J. S. Sidhu, Z. Kaposzta, H. S. Markus, and J. C. Kaski, “Effect of rosiglitazone on common carotid intima-media thickness progression in coronary artery disease patients without diabetes mellitus," Arteriosclerosis, Thrombosis, and Vascular Biology, vol. 24, pp. 930-934, 2004.

[108] B. Hedblad, A. Zambanini, P. Nilsson, L. Janzon, G. Berglund, et al., "Rosiglitazone and carotid IMT progression rate in a mixed cohort of patients with type 2 diabetes and the insulin resistance syndrome: main results from the Rosiglitazone Atherosclerosis Study," Journal of Internal Medicine, vol. 261, no. 3, pp. 293-305, 2007.

[109] D. J. Stocker, A. J. Taylor, R. W. Langley, M. R. Jezior, and R. A. Vigersky, "A randomized trial of the effects of rosiglitazone and metformin on inflammation and subclinical atherosclerosis in patients with type 2 diabetes," American Heart Journal, vol. 153, no. 3, pp. 445 e1-445 e6, 2007.

[110] T. Takagi, T. Akasaka, A. Yamamuro, et al., "Troglitazone reduces neointimal tissue proliferation after coronary stent implantation in patients with non-insulin dependent diabetes mellitus: a serial intravascular ultrasound study," Journal of the American College of Cardiology, vol. 36, no. 5, pp. 15291535, 2000.

[111] T. Takagi, A. Yamamuro, K. Tamita, et al., "Impact of troglitazone on coronary stent implantation using small stents in patients with type 2 diabetes mellitus," American Journal of Cardiology, vol. 89, no. 3, pp. 318-322, 2002.

[112] T. Takagi, T. Akasaka, A. Yamamuro, et al., "Impact of insulin resistance on neointimal tissue proliferation after coronary stent implantation. Intravascular ultrasound studies," Journal of Diabetes and Its Complications, vol. 16, no. 1, pp. 50-55, 2002.

[113] T. Takagi, A. Yamamuro, K. Tamita, et al., "Pioglitazone reduces neointimal tissue proliferation after coronary stent implantation in patients with type 2 diabetes mellitus: an intravascular ultrasound scanning study," American Heart Journal, vol. 146, no. 2, p. E5, 2003.

[114] K. Nishio, M. Sakurai, T. Kusuyama, et al., "A randomized comparison of pioglitazone to inhibit restenosis after coronary stenting in patients with type 2 diabetes," Diabetes Care, vol. 29, no. 1, pp. 101-106, 2006.

[115] N. Marx, J. Wohrle, and T. Nusser, "Pioglitazone reduces neointima volume after coronary stent implantation: a randomized, placebo-controlled, double-blind trial in nondiabetic patients," Circulation, vol. 112, no. 18, pp. 2792-2798, 2005.
[116] D. Choi, S.-K. Kim, S.-H. Choi, et al., "Preventative effects of rosiglitazone on restenosis after coronary stent implantation in patients with type 2 diabetes," Diabetes Care, vol. 27, no. 11, pp. 2654-2660, 2004.

[117] A. Osman, J. Otero, A. Brizolara, et al., "Effect of rosiglitazone on restenosis after coronary stenting in patients with type 2 diabetes," American Heart Journal, vol. 147, no. 5, pp. e21-e25, 2004.

[118] G. Wang, J. Wei, Y. Guan, N. Jin, J. Mao, and X. Wang, "Peroxisome proliferator-activated receptor- $\gamma$ agonist rosiglitazone reduces clinical inflammatory responses in type $2 \mathrm{di}$ abetes with coronary artery disease after coronary angioplasty," Metabolism: Clinical and Experimental, vol. 54, no. 5, pp. 590-597, 2005.

[119] D. M. Riche, R. Valderrama, and N. N. Henyan, "Thiazolidinediones and risk of repeat target vessel revascularization following percutaneous coronary intervention: a metaanalysis," Diabetes Care, vol. 30, no. 2, pp. 384-388, 2007.

[120] E. S. Rosmarakis and M. E. Falagas, "Effect of thiazolidinedione therapy on restenosis after coronary stent implantation: a meta-analysis of randomized controlled trials," American Heart Journal, vol. 154, no. 1, pp. 144-150, 2007.

[121] J. A. Dormandy, B. Charbonnel, D. J. Eckland, et al., "Secondary prevention of macrovascular events in patients with type 2 diabetes in the PROactive Study (PROspective pioglitAzone Clinical Trial in macroVascular Events): a randomised controlled trial," Lancet, vol. 366, no. 9493, pp. 1279-1289, 2005.

[122] E. Erdmann, J. A. Dormandy, B. Charbonnel, M. MassiBenedetti, I. K. Moules, and A. M. Skene, "The effect of pioglitazone on recurrent myocardial infarction in 2,445 patients with type 2 diabetes and Previous myocardial infarction. Results from the PROactive (PROactive 05) study," Journal of the American College of Cardiology, vol. 49, no. 17, pp. 1772-1780, 2007.

[123] R. Wilcox, M.-G. Bousser, D. J. Betteridge, et al., "Effects of pioglitazone in patients with type 2 diabetes with or without previous stroke: results from PROactive (PROspective pioglitAzone Clinical Trial in macroVascular Events 04)," Stroke, vol. 38, no. 3, pp. 865-873, 2007.

[124] J. B. Buse, "Action to control cardiovascular risk in diabetes (ACCORD) trial: design and methods," American Journal of Cardiology, vol. 99, no. 12, pp. S21-S33, 2007.

[125] M. M. Brooks, R. L. Frye, S. Genuth, et al., "Hypotheses, design, and methods for the bypass angioplasty revascularization investigation 2 diabetes (BARI 2D) trial," American Journal of Cardiology, vol. 97, no. 12, pp. 9-19, 2006.

[126] P. D. Home, S. J. Pocock, H. Beck-Nielsen, et al., "Rosiglitazone evaluated for cardiac outcomes and regulation of glycaemia in diabetes (RECORD): study design and protocol," Diabetologia, vol. 48, no. 9, pp. 1726-1735, 2005.

[127] S. E. Nissen and K. Wolski, "Effect of rosiglitazone on the risk of myocardial infarction and death from cardiovascular causes," The New England Journal of Medicine, vol. 356, no. 24, pp. 2457-2471, 2007.

[128] "NHLBI Statement on Use of Rosiglitazone in Two NHLBI-Funded Clinical Trials," http://public.nhlbi.nih.gov/ newsroom/home/GetPressRelease.aspx?id=287, 2007.

[129] P. D. Home, S. J. Pocock, H. Beck-Nielsen, et al., "Rosiglitazone evaluated for cardiovascular outcomes-an interim analysis," The New England Journal of Medicine, vol. 357, no. 1, pp. 28-38, 2007. 


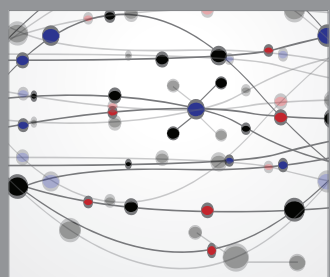

The Scientific World Journal
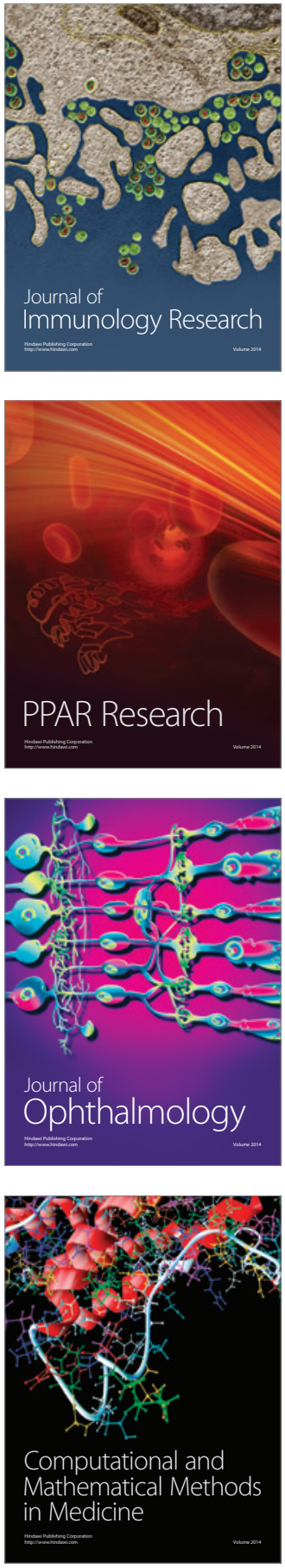

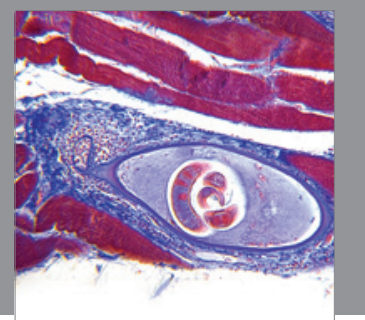

Gastroenterology

Research and Practice
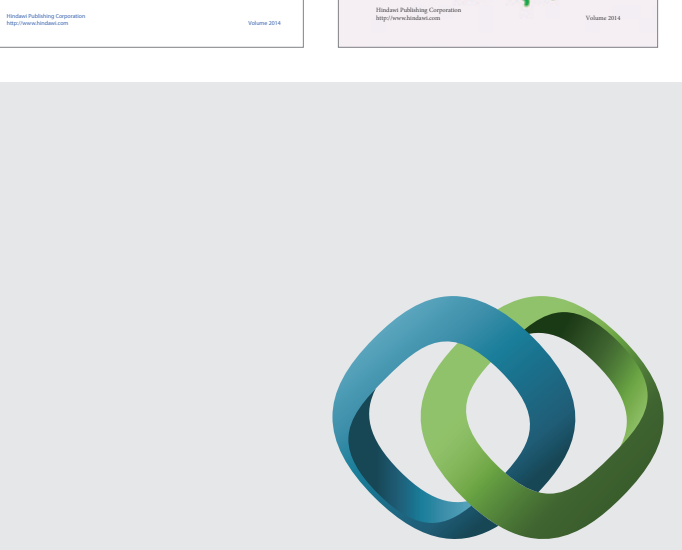

\section{Hindawi}

Submit your manuscripts at

http://www.hindawi.com
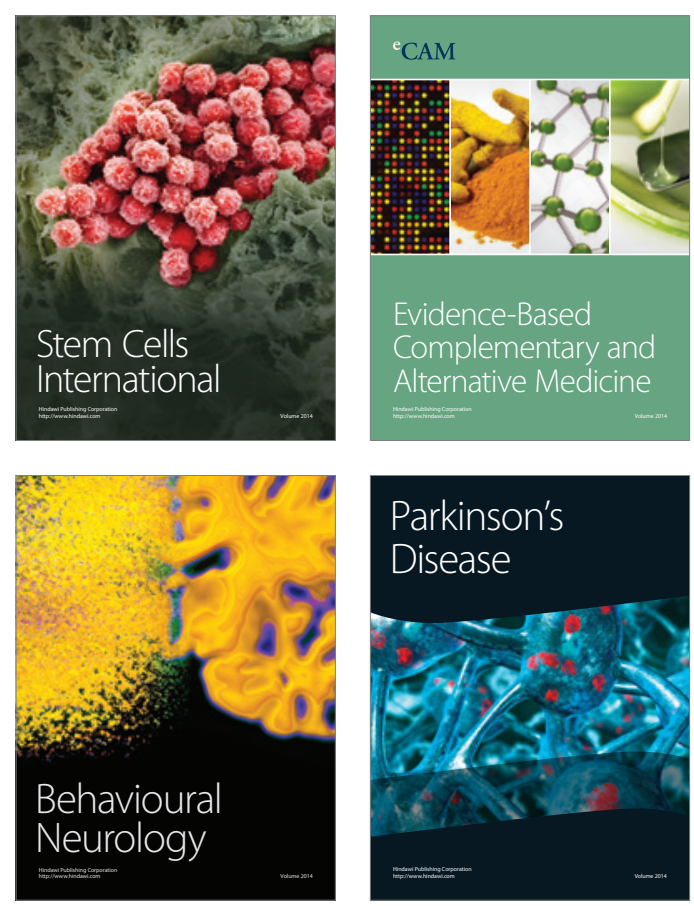

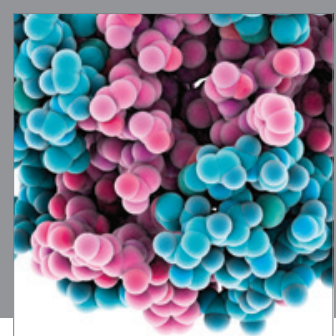

Journal of
Diabetes Research

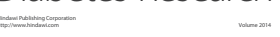

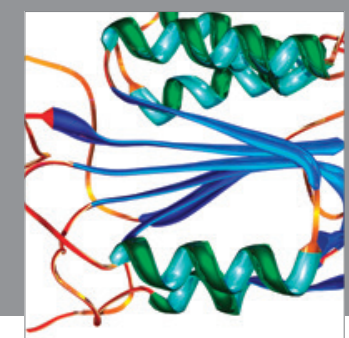

Disease Markers
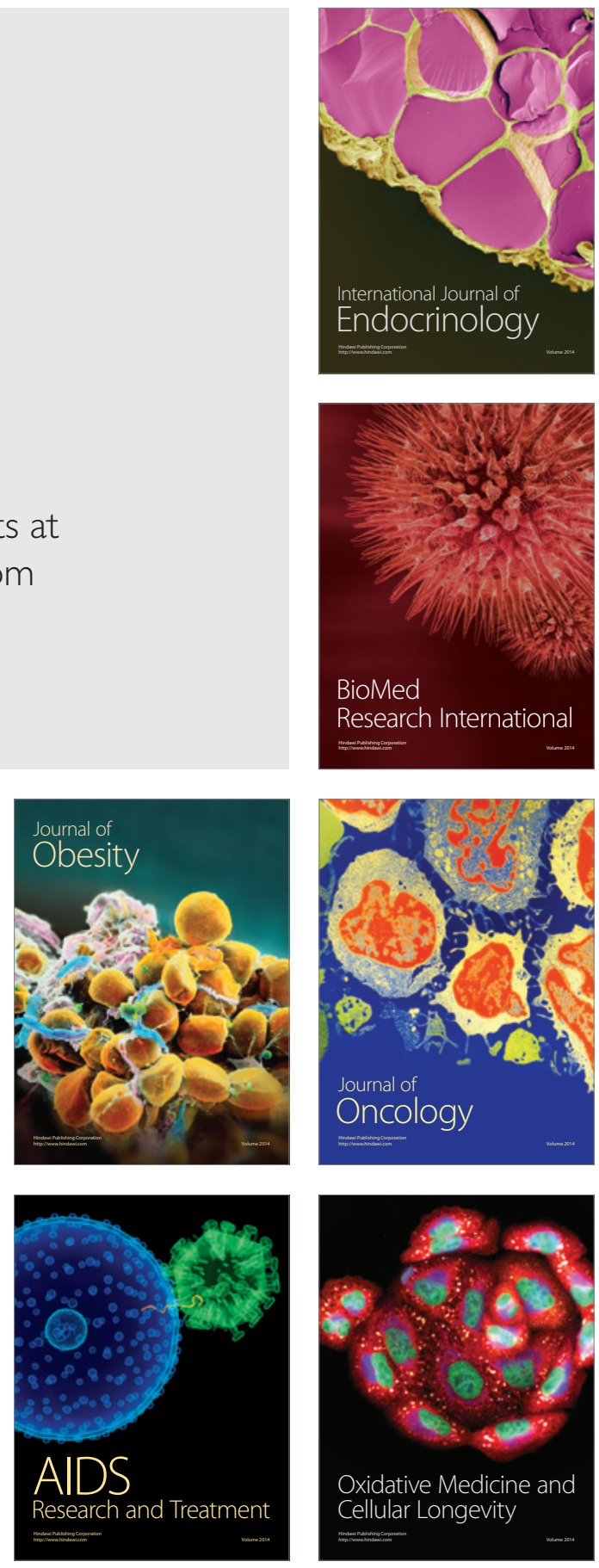